\title{
Correction to: Thermal database for the Indian region
}

\author{
Harini Guruhappa $^{1}$ - V. Pavan Kumar ${ }^{1}$ - D. V. Ramana ${ }^{1} \cdot$ Kirti Srivastava $^{1}$
}

Published online: 26 February 2022

(C) The Author(s), under exclusive licence to Springer-Verlag GmbH Germany, part of Springer Nature 2022

\section{Correction to: Earth Science Informatics https://doi.org/10.1007/s12145-021-00750-y}

In the original version of this article, the author name V. Pavan should have been written as V. Pavan Kumar.

The original article has been corrected.

Publisher's note Springer Nature remains neutral with regard to jurisdictional claims in published maps and institutional affiliations.

The online version of the original article can be found at https://doi.org/ $10.1007 / \mathrm{s} 12145-021-00750-\mathrm{y}$

Harini Guruhappa

g.harini07@gmail.com

1 CSIR- National Geophysical Research Institute, Hyderabad 500007, India 